\title{
25 Research Soure \\ Development of Loop mediated isothermal amplification (LAMP) assay for the detection of Magnaporthe oryzae causing blast in rice
}

Rajendran Lingan ( $\nabla$ rucklingraja@rediffmail.com )

TNAU: Tamil Nadu Agricultural University https://orcid.org/0000-0001-8840-7419

Gowrisri Nagaraj

TNAU: Tamil Nadu Agricultural University

Kamalakannan Ayyanar

TNAU: Tamil Nadu Agricultural University

Malathi Varagur Ganesan

TNAU: Tamil Nadu Agricultural University

Rajesh Subramanian

TNAU: Tamil Nadu Agricultural University

Karthick Marimuthu

TNAU: Tamil Nadu Agricultural University

\section{Research Article}

Keywords: Rice, blast, Magnaporthe oryzae, diagnosis and loop-mediated isothermal amplification (LAMP)

Posted Date: February 7th, 2022

DOI: https://doi.org/10.21203/rs.3.rs-1322856/v1

License: (1) (i) This work is licensed under a Creative Commons Attribution 4.0 International License. Read Full License 


\section{Abstract}

Rice is one of the most important nourishment crops providing a quarter of calories consumption. It alone contributes 23 per cent of calories consumed by people all over the world. Rice blast pathogen is an important ascomycetes fungus which causes severe yield losses up to 100 per cent under favorable climatic conditions. A field survey on rice blast disease revealed that the disease incidence was ranged from $50.1 \%-72.46 \%$ with the highest disease incidence of $72.46 \%$ at Coimbatore district, Tamil Nadu, India. Totally seven isolates of Magnaporthe oryzae were collected and the identity was confirmed through morphological and molecular confirmation. A loop-mediated isothermal amplification assay was developed by targeting Pita 2 gene sequence of $M$. oryzae. The assay developed was more sensitive as it detected the genomic DNA of M. oryzae up to $10 \mathrm{fg}$. The specificity of LAMP assay was proved by carrying out the assay with genomic DNA extracted from other fungal pathogens. Therefore, the LAMP assay developed will be helpful in rapid, specific and sensitive detection of rice blast pathogen at field level and will help in mitigating the disease incidence.

\section{Introduction}

Rice (Oryza sativa L.) is one of the most important cereal crops next to wheat and also most important staple food, which contributes approximately 30 per cent of nutritional intake (Gnanamanickam, 2009). It is widely grown in India, China and the rest of Asia where the maximum of 92 per cent of world's rice is grown. India is the second largest country in rice production next to China. The rice crop suffers from number of diseases, among the different diseases infecting rice, blast is one of the most destructive disease around the world. This disease was incited by a fungal pathogen called Magnaporthe oryzae (Synonym: Pyricularia oryzae Cavara) which results in extensive yield losses. Every year the rice crop will face severe yield losses up to $100 \%$ under favourable conditions (Liu et al., 2013). The pathogen M. oryzae is an ascomycetes fungus encompasses hundreds of races (pathotypes) around the world (Jia et al., 2014). The pathogen is quite capable to infect the rice plants at any stage of its growth period from seedling to grain formation and causes multifarious infection like leaf blast, collar rot, nodal blast and neck blast or panicle blast (Gowda et al., 2015). Therefore, it is necessary to identify the pathogen at earlier stage of its infection which helps to take up the timely management practices.

The identification of pathogens through morphometric analysis and molecular confirmation through nucleic acid based detection like PCR were time consuming, laborious and require skilled labours (Notomi et al., 2000). The sensitivity of the techniques was adversely affected by PCR inhibitors, particularly when inoculum levels are low or near detection limits. Loop mediated isothermal amplification assay (LAMP) is an novel detection technique, which was applied for the successful detection of several plant pathogens (Notomi et al., 2000, Thiessen et al., 2016, Tomlinson et al., 2010, Villari et al., 2017). This method requires DNA polymerase, and a set of four specially designed primers that recognize six different regions on the target DNA template. This method has been widely applied under field condition for on-site detection, because of its low cost, high specificity, efficiency, simplicity of operation and rapidity (Niessen and Vogel, 2010). The entire reaction will be completed under isothermal condition in conventional water bath.

In order to mitigate the yield losses and to take up timely management practices, early detection and efficient diagnosis of plant diseases are needed. LAMP is a rapid technique emerging as a quick diagnostic tool for advanced detection and identification of plant diseases. While this helps to improve research on detection and reduces time for detecting plant pathogens during field analysis. In this study, we have developed a LAMP assay protocol for rapid, early, specific and sensitive detection of $M$. oryzae infecting rice for the first time in India. 


\section{Materials And Methods}

Survey and pathogen isolation

A roving survey was conducted in Coimbatore and Erode districts of Tamil Nadu, India during Kharif season of 2018-19 in major rice growing areas to access the incidence of rice blast disease. The rice blast disease incidence was assessed by utilizing the scale of IRRI, 1996 as follows. 0- No lesion observed (Highly Resistant), 1- Small brown specks of pin point size (or) larger brown specks without sporulating centre (Resistant), 2-Small roundish to slightly elongated, necrotic gray spots, about 1-2 mm in diameter, with a distinct brown margin (Moderately Resistant), 3- Lesion type is the same as in scale 2, but significant numbers of lesions are on the upper leaves (Moderately Resistant), 4- Typical susceptible blast lesions of $3 \mathrm{~mm}$ or longer, infecting less than $4 \%$ of leaf area (Moderately Susceptible), 5- Typical blast lesions infecting 4-10\% of the leaf area (Moderately Susceptible), 6Typical blast lesions infecting $11-25 \%$ of the leaf area (Susceptible), 7 - Typical blast lesions infecting $26-50 \%$ of the leaf area (Susceptible), 8- Typical blast lesions infecting $51-75 \%$ of the leaf area many leaves are dead (Highly Susceptible), 9 - Typical blast lesions infecting more than $75 \%$ leaf area affected (Highly Susceptible). Finally, by using Mckinney (1923) formula, per cent disease index (PDI) of rice blast was calculated

\section{PDI $=\frac{\text { Sum of all numerical rating }}{\text { Total number of leaves observed }} \times \frac{100}{\text { Maximum grade in the score chart }}$}

A total of seven rice blast diseased leaf samples were collected from Coimbatore and Erode districts of Tamil Nadu, India. A fungus was constantly isolated from the blast infected leaves by tissue segment method on PDA medium. The cultures were maintained at $4^{\circ} \mathrm{C}$ for further identification and characterization.

\section{Morphological and molecular characterization of M. oryzae}

The actively growing mycelia were taken from the edge of 9 days old mother cultures of each isolate placed on PDA medium. The radial growth of different isolates was measured daily from the first day after inoculation until maximum growth on the Petri dishes. Radial growth of the isolates was compared on the 10th day after inoculation. The length and breadth of the conidia of seven $M$. oryzae isolates were measured using a light microscope of 400X magnification and photographed in Image Analyser. Molecular characterization of rice blast pathogen was done using fungal culture of all seven isolates. A fresh fungal culture from each isolates was inoculated into $100 \mathrm{ml}$ of PDA broth. A $100 \mathrm{~g}$ of 14 day's old dried fungal mat was harvested from the broth and subjected to genomic DNA isolation by Cetyl Trimethyl Ammonium Bromide (CTAB) method. The genomic DNA was checked by gel electrophoresis and DNA concentrations of the samples were determined using a spectrophotometer (Nanodrop, ND-1000, Wilmington, DE) and stored at $-20^{\circ} \mathrm{C}$ for further use. The conventional PCR was performed at $20 \mu \mathrm{l}$ mixture containing $2 \mu \mathrm{l}$ of genomic DNA ( 50 ng/ $\mu \mathrm{l}), 10 \mu \mathrm{l}$ of TaKaRa master mix (2 $\mathrm{X}$ concentration) and $2 \mu \mathrm{l}$ of each forward and reverse primers $(20 \mathrm{pmol})$. The reaction was carried out in eppendorf thermocycler. The PCR amplification of ITS region consisted of an initial denaturation of 4 minutes at $94^{\circ} \mathrm{C}$ followed by 40 cycles of 2 minutes of denaturation at $94^{\circ} \mathrm{C}, 45$ seconds of annealing at $53^{\circ} \mathrm{C}, 2$ minutes of extension at $72^{\circ} \mathrm{C}$ and a final extension for 10 minutes at $72^{\circ} \mathrm{C}$. The PCR program for the amplification of Pot 2 transposon region consisted of an initial denaturation of 4 minutes at $94^{\circ} \mathrm{C}$ followed by 40 cycles of 45 seconds 
of denaturation at $94^{\circ} \mathrm{C}, 45$ seconds of annealing at $55^{\circ} \mathrm{C}$, and 45 seconds of extension at $72^{\circ} \mathrm{C}$. The final extension was done for 10 minutes at $72^{\circ} \mathrm{C}$. The PCR amplified products were visualized under UV and the images were documented with an Alpha Imager EC (USA).

\section{LAMP primers designing}

The Pita 2 gene of M. oryzae was selected as a target site for designing LAMP primers. The primer sequences were designed using Primer Explorer version 5.0 software on the Eikon Genome site. All parameters viz., GC content, melting temperature, distance between the primer ends were as per the default setting.

\section{Optimization of LAMP reaction}

LAMP assay was performed using Magnaporthe oryzae DNA as template to determine the optimum reaction temperature and time. To determine the optimum temperature, the assay was tested with a range of temperature (56 to $68^{\circ} \mathrm{C}$ ) using pure DNA of $M$. oryzae and to determine the optimum time, the assay was tested with a range of time (30 to 120 minutes). The reaction was terminated by heat inactivation at $80{ }^{\circ} \mathrm{C}$ for 2 minutes.

To optimize the concentration of $\mathrm{MgSO}_{4}$ in the reaction mixture, a total of five different concentrations of $\mathrm{Mg}^{2+}$ $(2.00,4.00,6.00,8.00$ and $10.00 \mathrm{mM})$ were tested along with nuclease free water without $\mathrm{MgSO}_{4}$ (negative control). The concentration of other components such as LAMP primers, Thermophol reaction buffer, dNTPs, Bst DNA polymerase, betaine, hydroxynaptholblue (HNB) indicator, DNA template and water in LAMP assay was kept constant. The tubes containing $25 \mu \mathrm{l}$ reaction mixtures were incubated at $65^{\circ} \mathrm{C}$ for 60 minutes and reaction was terminated by heat inactivation at $80^{\circ} \mathrm{C}$ for 2 minutes. The results were reconfirmed by assessment using HNB, $\mathrm{EtBr}$, as well as resolving in 1.0 per cent agarose gel electrophoresis.

\section{LAMP specificity assay}

The specificity of LAMP assay was determined using the total genomic DNA isolated from M. oryzae and other plant pathogens like Helminthosporium oryzae infecting rice (Brown spot), Plasmopara viticola infecting grapes (Downy Mildew), Erysiphe necatorinfecting grapes (Powdery mildew), Fusarium oxysporum f. sp. cubense infecting banana (Panama wilt), Colletotrichum capsici infecting chilli (Chilli anthracnose), Pernoscleropsora sorghi infecting sorghum (Sorghum downy mildew) and Sclerospora graminicola infecting bajra (Cumbu downy mildew) along with nuclease free water serves as negative control. The reaction mixtures (25 $\mu$ ) with template DNA of different fungal pathogens in each tube were incubated at $65^{\circ} \mathrm{C}$ for 60 minutes and reaction terminated by heat inactivation at $80^{\circ} \mathrm{C}$ for 2 minutes. The specificity of the assay was assessed based on HNBvisualized color change, EtBr visualization and further confirmed with 1.0 per cent agarose gel electrophoresis.

\section{LAMP sensitivity assay}

The sensitivity of LAMP assay was evaluated by ten-fold serial dilution of purified genomic DNA of $M$. oryzae from 100 nano gram to 1 femto gram (100 ng, 10 ng, 1 ng, 100 pg, 10 pg, 1 pg, 100 fg, 10 fg and $1 \mathrm{fg}$ ). The $25 \mu \mathrm{l}$ of reaction mixtures with different concentration of serially diluted genomic DNA of M. oryzae in each tube 
were incubated at $65^{\circ} \mathrm{C}$ for 60 minutes and reaction was terminated by heat inactivation at $80^{\circ} \mathrm{C}$ for 2 minutes. The sensitivity of the assay was assessed based on HNB-visualized color change, EtBr visualization and further confirmed with 1.0 per cent agarose gel electrophoresis.

\section{Detection of M. oryzae by LAMP}

The LAMP assay was performed in a $25 \mu$ reaction mixture containing $1.4 \mu \mathrm{M}$ each of the FIP and BIP primers, 0.2 $\mu \mathrm{M}$ each of $\mathrm{F} 3$ and B3 primers, $0.4 \mu \mathrm{M}$ each of the LF and LB primers, $1.4 \mathrm{mM}$ each of dNTPs, $2.5 \mu \mathrm{l}$ of $10 \mathrm{X}$ Thermophol reaction buffer, $4 \mathrm{mM} \mathrm{MgSO}_{4}, 8 \mathrm{U}$ of Bst DNA polymerase (New England Biolabs, Ipswich, MA), $0.8 \mathrm{M}$ betaine solution, $120 \mu \mathrm{M}$ hydroxynaptholblue (HNB) indicator and $2.5 \mu \mathrm{l}$ of DNA ( 100 ng) template. The reaction tubes were incubated at $65^{\circ} \mathrm{C}$ for 60 minutes and terminated by thermal inactivation at $80^{\circ} \mathrm{C}$ for 2 minutes in eppendorf thermal cycler. The LAMP amplicons were visualized by different strategies: (a) visualization under hydroxy naphthol blue (HNB), (b) visualization under ethidium bromide (EtBr) and (c) 1.0 per cent agarose gel electrophoresis.

\section{Results}

\section{Survey and pathogen isolation}

Field survey results indicated that the highest incidence of rice blast infection was observed in Poosaripalayam village of Coimbatore district with PDI of $72.46 \%$, followed by $67.75 \%, 60.63 \%$ in Booluvampatti and Bhavanisagar, respectively. The Gobichettipalayam village of Erode district showed the lowest incidence of $50.10 \%$ (Table 1). A fungus was constantly isolated from the rice leaf samples showing spindle shaped lesions on PDA medium. A total of seven isolates were isolated from infected leaf samples and stored at $4^{\circ} \mathrm{C}$ for characterization (Figure 1).

\section{Morphological and molecular characterization of M. oryzae}

The fungus mycelium was hyaline, septate and branched. The conidiophores were thin walled, slender and unbranched. The fungus produced pyrifom conidia with 2 septation and hilum at base (Figure 2). The genomic DNA samples of $M$. oryzae obtained from mycelium of all the seven isolates were subjected to PCR amplification using universal primers ITS 1 and ITS 4. PCR amplification yielded a fragment of expected amplicon size of 550 bp (Figure 3). The amplified products of all the isolates was sequenced at Eurofins genomics India Pvt. Ltd. and confirmed as M. oryzae by comparing with the sequences already deposited in NCBI database. The comparison of nucleotide sequences showed an identity of $97-100 \%$ with the M. oryzae isolates available in GenBank (CP034204, MH859782, MF583153, LK932250, MF583148, KJ522980 and KM816801). The sequences of all seven isolates were deposited in GenBank and accession numbers were obtained (Table 2). The genomic DNA samples were further amplified using species specific primer set targeting Pot 2 transposon gene. The PCR amplification generated an amplicon size of approximately 680 bp for all the seven isolates authenticating the fungus as M. oyzae (Figure 4). 


\section{LAMP primers designing}

The Pita 2 gene sequence (GenBank accession no: AB607344) of $M$. oryzae was selected as the target region for designing of LAMP primers. We hypothesized that targeting the specific gene sequence (Pita 2) through LAMP assay may be more appropriate for accurate detection with 100 per cent efficiency. There are totally six primers (inner primers (FIP and BIP), outer primers (F3 and B3) and Loop primers (F loop and B loop)) designed using Primer Explorer v. 5 software. The designed primers were projected in Table 3.

\section{LAMP optimization}

The optimum LAMP reaction conditions such as temperature and time for the detection of Magnaporthe oryzae were determined. Among the five different temperatures tested, positive reaction of sky blue color change was observed at almost all the temperature except at $56^{\circ} \mathrm{C}$. However, the amplification efficiency exhibited a strong increase at $65^{\circ} \mathrm{C}$, where the discrete ladder like pattern was more consistent and emitted a strong fluorescence under EtBr visualization (Table 4 and Figure 5). When the LAMP was performed at $65^{\circ} \mathrm{C}$ with range of test time, colour change was observed at two different temperatures. However, the amplification efficiency exhibited a strong increase at 60 minutes of incubation time under HNB visualization, EtBr fluorescence and the discrete ladder like pattern was more consistent at the same test time (Table 5 and Figure 6).

Among five different concentrations of $\mathrm{Mg}^{2+}(2.00,4.00,6.00,8.00$ and $10.00 \mathrm{mM})$ tested, the colour change was observed only at 4.00, 6.00 and $8.00 \mathrm{mM}$ of $\mathrm{Mg}^{2+}$. However, the strong sky blue colour development was observed at $4.00 \mathrm{mM}$ of $\mathrm{Mg}^{2+}$ with bright fluorescence under EtBr visualization. The discrete ladder like pattern was more intense at the same test concentration indicating that the optimum concentration of $\mathrm{MgSO}_{4}$ for the effective detection of Magnaporthe oryzae was $4.00 \mathrm{mM}$ (Table 6 and Figure 7).

\section{LAMP specificity assay}

The specificity of LAMP assay was tested with 8 fungal pathogens with two indicator dyes like HNB and EtBr. The genomic DNA of fungal pathogens like Magnaporthe oryzae, Helminthosporium oryzae, Plasmopara viticola, Fusarium oxysporum f.sp. cubense, Colletotrichum capsici, Erysiphe necator, Pernoscleropsora sorghi and Sclerospora graminicola were subjected to LAMP assay. After incubation of LAMP reaction mixture at $65{ }^{\circ} \mathrm{C}$ for 60 minutes, a strong sky blue color development was observed only with M. oryzae DNA. However, LAMP reactions with the templates of other fungal isolates remained violet, indicating the absence of target DNA. A similar kind of results was obtained with the LAMP assay performed using EtBr indicator dye. The LAMP reaction with $M$. oryzae DNA developed a strong fluorescence, whereas the LAMP reaction with other non target pathogens did not produce fluorescence. The above results were confirmed using agarose gel electrophoresis. A discrete intense ladder like banding pattern was observed only in LAMP products with M. oryzae DNA. Ladder like banding pattern was absent in LAMP products with other fungal isolates and nuclease free water (negative control). This indicated that the developed LAMP assay was highly specific for the detection of $M$. oryzae (Table 7 and Figure 8).

\section{LAMP sensitivity assay}


To determine the detection limit of LAMP assay, a sensitivity test was performed with different DNA concentration of $M$. oryzae with two indicator dyes namely HNB and EtBr. The results showed that the sky blue color development was visible in almost all the concentration of genomic DNA tested, except at $1 \mathrm{fg}$. A similar kind of results was obtained while performing the test with $\mathrm{EtBr}$ dye. LAMP reaction with $\mathrm{EtBr}$ produced fluorescence from $100 \mathrm{ng}$ to $10 \mathrm{fg}$ except $1 \mathrm{fg}$ of genomic DNA. The above results were confirmed using agarose gel electrophoresis assay where discrete ladder-like banding pattern was visible upto $10 \mathrm{fg}$ DNA concentration. These results indicated that the developed LAMP assay could detect up to $10 \mathrm{fg}$ of DNA of M. oryzae (Figure 9).

\section{Detection of M. oryzae by LAMP}

The LAMP assay specific to $M$. oryzae was developed and tested against genomic DNA of seven isolates of $M$. oryzae study isolates with two indicator dyes such as HNB and EtBr. The strong sky blue color development was observed in all the tubes containing DNA of M. oryzae isolates. However, the tube with nuclease free water as a negative control did not showed any sky blue color development, indicating the absence of M. oryzae DNA.

A similar kind of results was obtained in LAMP reaction with $\mathrm{EtBr}$ indicator dye, where a strong fluorescence was observed in all the tubes containing genomic DNA of $M$. oryzae. The absence of fluorescence in the tube with nuclease free water indicated the absence of target DNA. The above LAMP products were confirmed with 1 per cent agarose gel electrophoresis assay. Agarose gel electrophoresis assay yielded a discrete ladder-like banding pattern for genomic DNA from M. oryzae isolates. Whereas no such ladder-like banding pattern was observed with nuclease free water (Figure 10).

\section{Discussion}

M. oryzae causing rice blast disease is a major threat to rice cultivation at global level. A quick and on-site detection of pathogens will bring down the chances for the failure of rice crop thereby improves the yield. The conventional detection of rice blast pathogen based on symptoms and PCR which are time consuming and require skilled labor. LAMP assay is a rapid and more sensitive detection technique and it can be detected more number of samples at a time. Recently, many plant pathogens viz., Magnaporthe grisea, Alternaria solani, Plasmopara viticola, Erysiphe necator, Puccinia graminis f.sp. tritici has been successfully detected using LAMP assay. It has several advantages over conventional PCR assay such as amplification of DNA at very low concentration, specific detection within 20 to 60 minutes, can be performed using water bath and visual interpretation of results with the help of indicator dyes. In present study, we strongly recommend LAMP assay for the on-site detection of rice blast pathogen, since it requires minimum quantity of DNA (10 fg) which is much lesser than that of the quantity required for conventional PCR. To the best of our knowledge, this is the first report of application of LAMP assay in India for the detection of $M$. oryzae infecting rice.

LAMP assay can detect the presence of pathogen within in 60 minutes by specific amplification of DNA which is more reliable and less time bound. Therefore, it can be used as a rapid diagnostic kit. It amplifies DNA under isothermal conditions and therefore, visual observation in a single reaction is possible. The time consumed in reconfirmation of amplified products (positive reaction) under gel electrophoresis can be eliminated due to change in turbidity of the reaction mixture because of the deposition of magnesium pyrophosphate which serves as a simple identification technique under naked eye. LAMP primers are designed in such a way that it can recognize six distinct regions of the target site leaving no space for false positive or false negative results. In PCR, only two 
regions can be recognized which results in more chances of amplifying false positives and false negatives and leaving the accuracy of detection under question. In present study, a set of six primers were designed using Primer Explorer v. 5 software to target the Pita 2 gene specific to $M$. oryzae and there is no cross reaction observed. The designed LAMP primers were highly sensitive and more specific in detecting $M$. oryzae thereby differentiating them from other tested pathogens. Ortega et al., (2018) designed LAMP primers for the detection of M. oryzae in rice seeds by targeting calmodulin gene. Likewise, Villari et al., (2017) designed LAMP primers targeting the gene sequence $L P K Y$ 97- 1 of $M$. oryzae isolates from rye grass using primer explorer v.4 software tool which is in accordance with our present study.

The LAMP reaction conditions like incubation temperature, time and $\mathrm{MgSO}_{4}$ concentration were optimized for the effective detection of Pita 2 gene of $M$. oryzae. The temperature is highly essential in strand displacement activity. Both a high or low temperature conditions may results in development of false positives and false negatives in LAMP assay. Therefore, an optimum temperature condition is highly essential for reliable detection of target pathogen. In this present study, the optimum temperature was found to be $65^{\circ} \mathrm{C}$ which is in accordance the results of Patel et al., (2015) who identified the optimum temperature for the detection of Rhizoctonia solani as $65^{\circ} \mathrm{C}$. Similarly, Dong et al., (2015) found the optimum temperature condition as $64.5^{\circ} \mathrm{C}$ for the detection of Phytophthora capsici using range of temperature from $62^{\circ} \mathrm{C}-65^{\circ} \mathrm{C}$. Lan et al., (2018) developed LAMP assay for sensitive and specific detection of Fusarium oxysporum f.sp. cucumerinum Owen causing Fusarium wilt in cucumber within 60 minutes of incubation. The LAMP assay developed by Ghosh et al., (2016) to detect Fusarium oxysporum f.sp. ciceris causing Fusarium wilt in chickpea requires 60 minutes of incubation which is in concurrence with our present study.

The concentration of $\mathrm{MgSO}_{4}$ is the most crucial component in LAMP mixture, since it highly influences the assay results when added in little quantities and also gives irrelevant results like positive amplification of negative samples when added in more amounts. This is because of binding of primers to an incorrect template. Hence, an optimum amount is highly essential for the best outcome of LAMP assay (Cao et al., 2016). In this present study, the optimum concentration of $\mathrm{MgSO}_{4}$ for the effective detection of $M$. oryzae was standardized as $4.00 \mathrm{mM}$. The results of our study was on par with the results of Duan et al., (2014) who has evaluated different concentration of $\mathrm{MgSO}_{4}$ from 2.0-4.50 mM and found that optimum concentration of $\mathrm{MgSO}_{4}$ for detection of Colletotrichum falcatum (red rot of sugarcane) was $4.0 \mathrm{mM}$. Similarly, Cao et al., (2016) evaluated the $\mathrm{MgSO}_{4}$ concentration from 5.0 - $8.0 \mathrm{mM}$ for LAMP based diagnosis of Ustilago maydis (common smut of corn). They optimized that $6.0 \mathrm{mM}$ to $8.0 \mathrm{mM}$ were effective for the detection of Ustilago maydis. The LAMP assay is highly sensitive in nature and it can detect the target pathogen even in samples with low concentration of DNA. In our present study, the LAMP assay developed for the detection of M.oryzae has an ability to detect upto $10 \mathrm{fg}$ of DNA concentration. Our results are in concurrence with the LAMP assay developed by Zhang et al., (2019) for the detection of Fusarium fujikuroi infecting rice crop, wherein the assay could detect the presence of pathogen at $10 \mathrm{fg}$ level of DNA concentration.

LAMP assay serves as a promising diagnostic kit, by forecasting the pathogen in advance. This will aid in designing of effective prediction models for the outbreak of diseases. Since, the early detection of the pathogen is achieved the protective measures can be taken much earlier by application of prophylactic fungicides.

\section{Declarations}




\section{Acknowledgements}

Authors like to acknowledge the Dean SPGS, Tamil Nadu Agricultural University, Coimbatore and the Professor and Head, Department of Plant Pathology, Tamil Nadu Agricultural University, Coimbatore, for their full support in this study.

\section{Funding}

The support provided by DST-SERB-EEQ, New Delhi, DST - FIST (Department of Science and Technology, New Delhi) for infrastructure facilities and UGC SAP (Project no: C30 AAH) and Department of Agriculture, Government of Tamil Nadu for providing financial support are acknowledged.

\section{Conflicts of interest/Competing interests:}

The authors declare that they no conflicts of interest.

\section{Ethics statement:}

There was no involvement of Human Participants and/or Animals in this research and hence ethical approval is not required

\section{Consent to Participate (Ethics)}

- All participants were informed and agreed.

\section{Consent to Publish (Ethics) -}

All the authors agreed to publish

\section{Authors' contributions:}

NG-survey, experimentation, analysis, validation, writing, AK-conceptualization, survey, methodology, writing, original draft preparation, VGM- conceptualization, methodology, writing, SR-methodology, writing, review and editing, MK-validation, analysis and LR- methodology, writing and editing.

\section{Availability of data and material:}

All the data generated or analyzed during this study are included in this manuscript.

\section{References}


1. Cao, Yanyong, Yongqiang Li, Jingjing Li, Lifeng Wang, Zeqiang Cheng, Hao Wang, Zaifeng Fan, and Huiyong Li. (2016) Rapid and quantitative detection of Pythium inflatum by real-time fluorescence loop-mediated isothermal amplification assay. Eur. J. Plant Pathol. 144 (1):83-95.

2. Dong, Zhongmei, Peiqing Liu, Benjin Li, Guoliang Chen, Qiyong Weng, and Qinghe Chen. (2015) Loopmediated isothermal amplification assay for sensitive and rapid detection of Phytophthora capsici. Can. J. Plant Pathol. 37 (4):485-494.

3. Duan, Ya-Bing, Chang-Yan Ge, Xiao-Ke Zhang, Jian-Xin Wang, and Ming-Guo Zhou. (2014) Development and evaluation of a novel and rapid detection assay for Botrytis cinerea based on loop-mediated isothermal amplification. Plos One 9 (10):e111094.

4. Ghosh, RAJU, AVIJIT Tarafdar, and MAMTA Sharma. (2016) Rapid detection of Fusarium oxysporum f. sp. ciceris from disease infested chickpea fields by loop-mediated isothermal amplification. Indian Phytopathol. 69 (4):47-50.

5. Gnanamanickam, Samuel S. (2009) Rice and its importance to human life. In Biological control of rice diseases, 1-11. Springer.

6. Gowda, Malali, Meghana D Shirke, HB Mahesh, Pinal Chandarana, Anantharamanan Rajamani, and Bharat B Chattoo. (2015) Genome analysis of rice-blast fungus Magnaporthe oryzae field isolates from southern India. Genom. Data 5: 284-291.

7. Jia, Yulin, Yeshi A Wamishe, and Bo Zhou. (2014) An expedited method for isolation of DNA for PCR from Magnaporthe oryzae stored on filter paper. CROP J 2 (5):267-271.

8. Lan, Chengzhong, Hongcheng Ruan, Xiujuan Yang, Jinai Yao, and Junxi Jiang. (2018) Development of a loopmediated isothermal amplification assay for sensitive and specific detection of Fusarium oxysporum $\mathrm{f}$. $\mathrm{sp}$. cucumerinum Owen. PHYTOPARASITICA 46 (3):283-293.

9. Liu, Yan, Bin Liu, Xiaoyuan Zhu, Jianyuan Yang, Alicia Bordeos, Guoliang Wang, Jan E Leach, and Hei Leung. (2013) Fine-mapping and molecular marker development for Pi56 (t), a NBS-LRR gene conferring broadspectrum resistance to Magnaporthe oryzae in rice. Theor. Appl. Genet 126 (4):985-998.

10. Mckinney, H. H. (1923) A new system of grading of plant diseases. J Agric. Res. 26: 195-218.

11. Niessen, Ludwig, and Rudi F Vogel. (2010) Detection of Fusarium graminearum DNA using a loop-mediated isothermal amplification (LAMP) assay. Int. J. Food Microbio/ 140 (2-3):183-191.

12. Notomi, Tsugunori, Hiroto Okayama, Harumi Masubuchi, Toshihiro Yonekawa, Keiko Watanabe, Nobuyuki Amino, and Tetsu Hase. (2000) Loop-mediated isothermal amplification of DNA. Nucleic Acids Res. 28 (12):e63-e63.

13. Ortega, Sara Franco, Jenny Tomlinson, Jennifer Hodgetts, Davide Spadaro, Maria Lodovica Gullino, and Neil Boonham. (2018) Development of Loop-Mediated Isothermal Amplification Assays for the Detection of Seedborne Fungal Pathogens Fusarium fujikuroi and Magnaporthe oryzae in Rice Seed. Plant Dis. 102 (8):1549-1558.

14. Patel, Jaimin S, Mary S Brennan, Aftab Khan, and Gul Shad Ali. (2015) Implementation of loop-mediated isothermal amplification methods in lateral flow devices for the detection of Rhizoctonia solani. Can. J. Plant Pathol. 37 (1):118-129.

15. Thiessen, LD, JA Keune, TM Neill, WW Turechek, GG Grove, and WF Mahaffee. (2016) Development of a grower-conducted inoculum detection assay for management of grape powdery mildew. PLANT PATHOL. 65 (2):238-249. 
16. Tomlinson, JA, MJ Dickinson, and N Boonham. (2010) Detection of Botrytis cinerea by loop-mediated isothermal amplification. Lett. Appl. Microbiol. 51 (6):650-657.

17. Villari, Caterina, Walter F Mahaffee, Thomas K Mitchell, Kerry F Pedley, Michael L Pieck, and Francesca Peduto Hand. (2017) Early detection of airborne inoculum of Magnaporthe oryzae in turfgrass fields using a quantitative LAMP assay. Plant Dis. 101 (1):170-177.

18. Zhang, SY, DJ Dai, HD Wang, and CQ Zhang. (2019) One-step loop-mediated isothermal amplification (LAMP) for the rapid and sensitive detection of Fusarium fujikuroi in bakanae disease through NRPS31, an important gene in the gibberellic acid bio-synthesis. Sci. Rep 9 (1):3726.

\section{Tables}

Table 1

Collection of blast infected rice leaves from different places of Coimbatore and Erode district

\begin{tabular}{|c|c|c|c|c|c|c|c|}
\hline S.no & District & $\begin{array}{l}\text { Isolation } \\
\text { code }\end{array}$ & Location & Variety & Latitude $\left({ }^{\circ} \mathrm{N}\right)$ & Longitude $\left({ }^{\circ} \mathrm{E}\right)$ & $\begin{array}{l}\% \\
\text { Disease } \\
\text { index }\end{array}$ \\
\hline 1. & Coimbatore & CBE 1 & Veerakeralam & CO 39 & $10.5943^{\circ} \mathrm{N}$ & $76.5459^{\circ} \mathrm{E}$ & $58.23^{d}$ \\
\hline 2. & Coimbatore & CBE 2 & Poosaripalayam & CO 39 & $11.0073^{\circ} \mathrm{N}$ & $76.9110^{\circ} \mathrm{E}$ & $72.46^{\mathrm{a}}$ \\
\hline 3. & Coimbatore & CBE 3 & Anaimalai & $\mathrm{CO} 43$ & $10.5826^{\circ} \mathrm{N}$ & $76.9528^{\circ} \mathrm{E}$ & $51.80^{f}$ \\
\hline 4. & Coimbatore & CBE 4 & Booluvampatti & $\mathrm{CO} 46$ & $10.9921^{\circ} \mathrm{N}$ & $76.7221^{\circ} \mathrm{E}$ & $67.75^{b}$ \\
\hline 5. & Erode & BSR & Bhavanisagar & Bhavani & $11.288^{\circ} \mathrm{N}$ & $77.722{ }^{\circ} \mathrm{E}$ & $60.63^{c}$ \\
\hline 6. & Erode & SAT & Sathyamangalam & $\mathrm{CO} 46$ & $11.5048^{\circ} \mathrm{N}$ & $77.2384^{\circ} \mathrm{E}$ & $54.29^{e}$ \\
\hline \multirow[t]{2}{*}{7.} & Erode & GB & Gobichettipalayam & $\mathrm{CO} 46$ & $11.4504^{\circ} \mathrm{N}$ & $77.4300^{\circ} \mathrm{E}$ & $50.10^{\mathrm{g}}$ \\
\hline & & & & & & & $\begin{array}{l}C D \\
(0.05)= \\
1.74\end{array}$ \\
\hline
\end{tabular}

Note: * Mean of three replications.

Means in a column followed by same superscript letters are not significantly different according to DMRT at P $\leq$ 0.05 .

t according to DMRT at $\mathrm{P} \leq 0.05$.

Table 2

Accession number of ITS region of study isolates of Magnaporthe oryzae 


\begin{tabular}{|llll|}
\hline S. No. & Place & Study isolate name & Accession number \\
\hline 1. & Veerakeralam & CBE 1 & MK880270 \\
\hline 2. & Poosaripalayam & CBE 2 & MK880271 \\
\hline 3. & Anaimalai & CBE 3 & MK937810 \\
\hline 4. & Booluvampatti & CBE 4 & MN067714 \\
\hline 5. & Bhavanisagar & BSR & MK880269 \\
\hline 6. & Sathyamangalam & SAT & MK937811 \\
\hline 7. & Gobichettipalayam & GB & MN067715 \\
\hline
\end{tabular}

Table 3

Sequences of LAMP primers designed

\begin{tabular}{|lllr|}
\hline $\begin{array}{l}\text { LAMP assay (gene } \\
\text { target) }\end{array}$ & Primer & Primer sequence (5'-3') & Length \\
AVR Pita 2 & FIP & GCGACGTCGATAAAGGTATCACCCCATGAGATCACCAGACC & $41 \mathrm{nt}$ \\
\hline BIP & AGCTCAGAACTTTGTTTGTTTCCTTCATAGCACGGAAGCTAGT & $43 \mathrm{nt}$ \\
\hline F3 & CCTAATTACTGTGACATTTGGA & $22 \mathrm{nt}$ \\
\hline B3 & GTAATTGTCACGGCCAGG & $18 \mathrm{nt}$ \\
\hline F & GGTCAGGGGTCAGGGTTAG & $19 \mathrm{nt}$ \\
\hline Loop & & $25 \mathrm{nt}$ \\
\hline Loop & GAGTAGAATCTTCGTCGATAGATGC & \\
\hline
\end{tabular}

Table 4

Optimization of incubation temperature in LAMP assay for the detection of $M$. oryzae

\begin{tabular}{|lllll|}
\hline S. No. & Temperature $\left({ }^{\circ} \mathrm{C}\right)$ & Colour change with HNB & Fluorescence with EtBr & DNA amplification* \\
\hline 1. & 56 & Violet & No fluorescence & - \\
\hline 2. & 59 & Weak Sky blue & Very dull fluorescence & + \\
\hline 3. & 62 & Mild Skyblue & Dull fluorescence & ++ \\
\hline 4. & 65 & Strong Sky blue & Bright fluorescence & +++ \\
\hline 5. & 68 & Weak Sky blue & Very dull fluorescence & + \\
\hline
\end{tabular}

*Where,

+++ : Strong DNA amplification 
+ + : Mild DNA amplification

+ : Weak DNA amplification

- : No amplification

Table 5

Optimization of incubation time in LAMP assay for the detection of M. oryzae

\begin{tabular}{|lll|}
\hline S. No. & $\begin{array}{l}\text { Incubation Time } \\
(\min .)\end{array}$ & DNA amplification* \\
\hline 1. & 30 & - \\
\hline 2. & 60 & ++ \\
\hline 3. & 90 & + \\
\hline 4. & 120 & - \\
*Where, & \\
++ & $:$ & Strong DNA amplification \\
+ & $:$ & Mild DNA amplification \\
- & $:$ & No amplification \\
\hline
\end{tabular}

Table 6

Optimization of $\mathrm{MgSO}_{4}$ concentration in LAMP assay for the detection of $\mathrm{M}$. oryzae

\begin{tabular}{|c|c|c|c|c|}
\hline S. No. & $\begin{array}{l}\mathrm{MgSO}_{4} \text { concentration } \\
(\mathrm{mM})\end{array}$ & Colour change with HNB & Fluorescence with EtBr & DNA amplification* \\
\hline 1. & 2 & Violet & No fluorescence & - \\
\hline 2. & 4 & Strong Sky blue & Bright fluorescence & +++ \\
\hline 3. & 6 & Mild Sky blue & Dull fluorescence & ++ \\
\hline 4. & 8 & Weak Sky blue & Very dull fluorescence & + \\
\hline 5. & 10 & Violet & No fluorescence & - \\
\hline 6. & 0 & violet & No fluorescence & _ \\
\hline
\end{tabular}

*Where,

$++\quad$ : Strong DNA amplification 


\section{$+\quad$ : Mild DNA amplification}

+ : Weak DNA amplification

- : No amplification

Table 7

Specificity of LAMP assay for the detection of M. oryzae

\begin{tabular}{|c|c|c|c|c|}
\hline S. No. & Cultures & Host & Accession no. & DNA amplification* \\
\hline 1. & Magnaporthe oryzae & Rice & MK880271 & + \\
\hline 2. & Helminthosporium oryzae & Rice & MN901494 & - \\
\hline 3. & Plasmopara viticola & Grapes & GQ258976 & - \\
\hline 4. & Erysiphe necator & Grapes & MK637521 & - \\
\hline 5. & Fusarium oxysporum f.sp. cubense & Banana & MF576349 & - \\
\hline 6. & Colletotrichum capsici & Chilli & MF280216 & - \\
\hline 7. & Pernoscleropsora sorghi & Sorghum & MK453403 & - \\
\hline 8. & Sclerospora graminicola & Bajra & MK453404 & - \\
\hline 9. & $\begin{array}{l}\text { Negative control } \\
\text { (Nuclease free water) }\end{array}$ & - & & - \\
\hline \multicolumn{5}{|c|}{$\begin{array}{l}\text { *Where, } \\
+\quad: \text { Positive amplification }\end{array}$} \\
\hline
\end{tabular}

Figures 


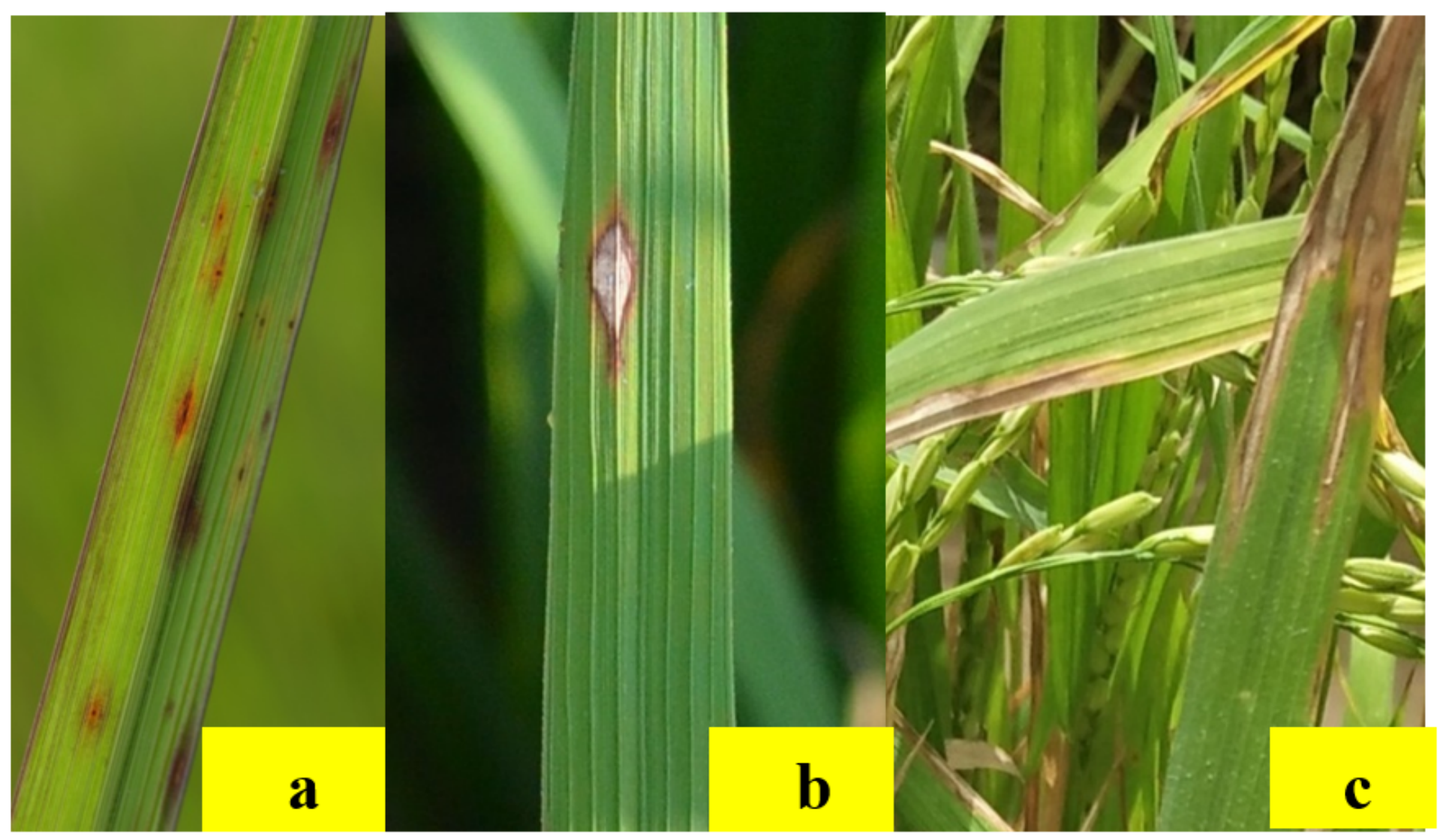

Figure 1

Collection of blast infected rice leaves from farmer's field.

Legand - (a) Development of individual spots at early stage of infection (b) Spindle shaped lesions on rice leaves (c) Drying of leaves 


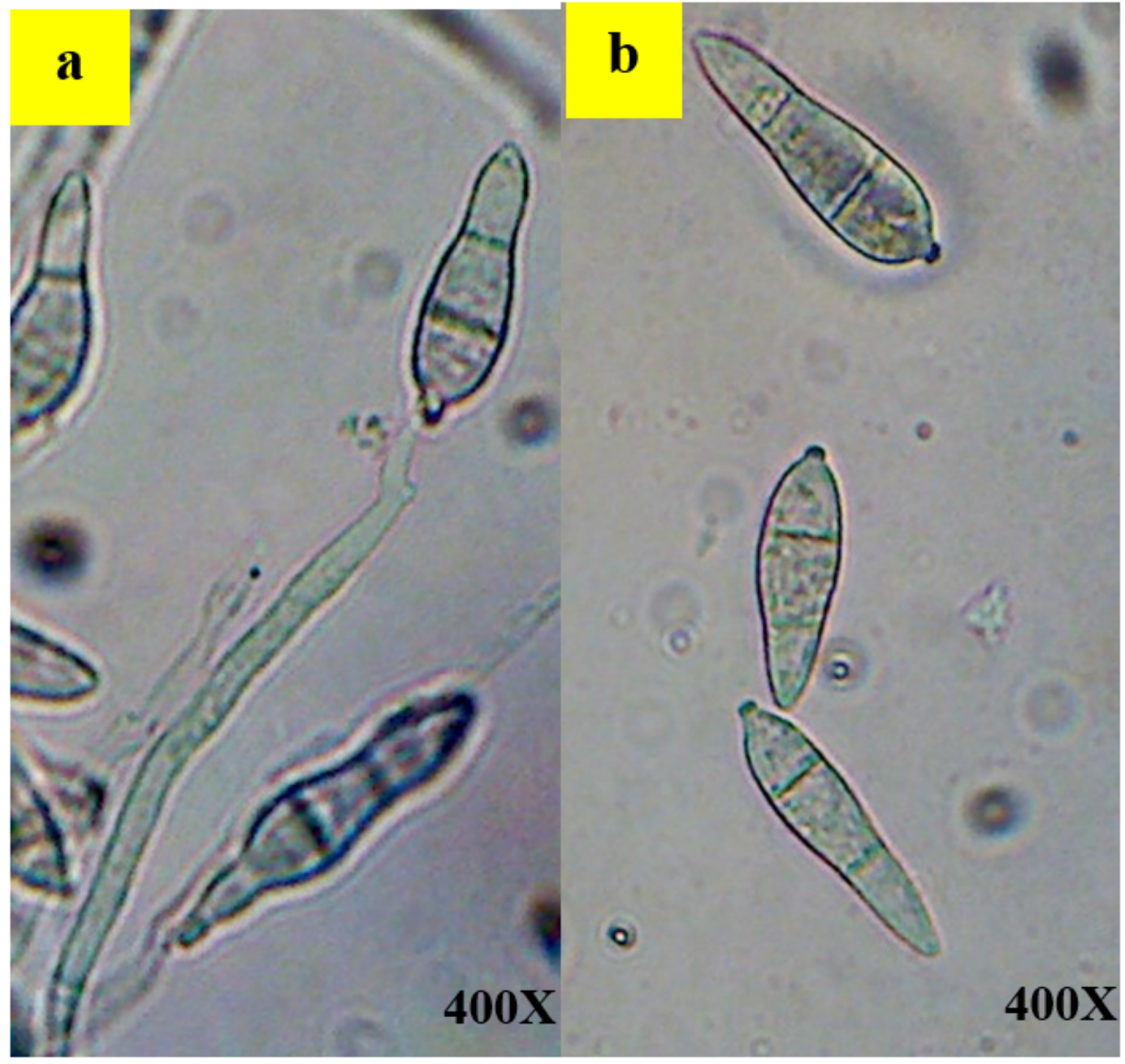

Figure 2

Morphological characterization of $M$. oryzae conidiophore at 400X magnification.

Legand- (a) Hyaline, septate conidiophore with conidia. (b) Three celled pyriform conidia with hilum at base 


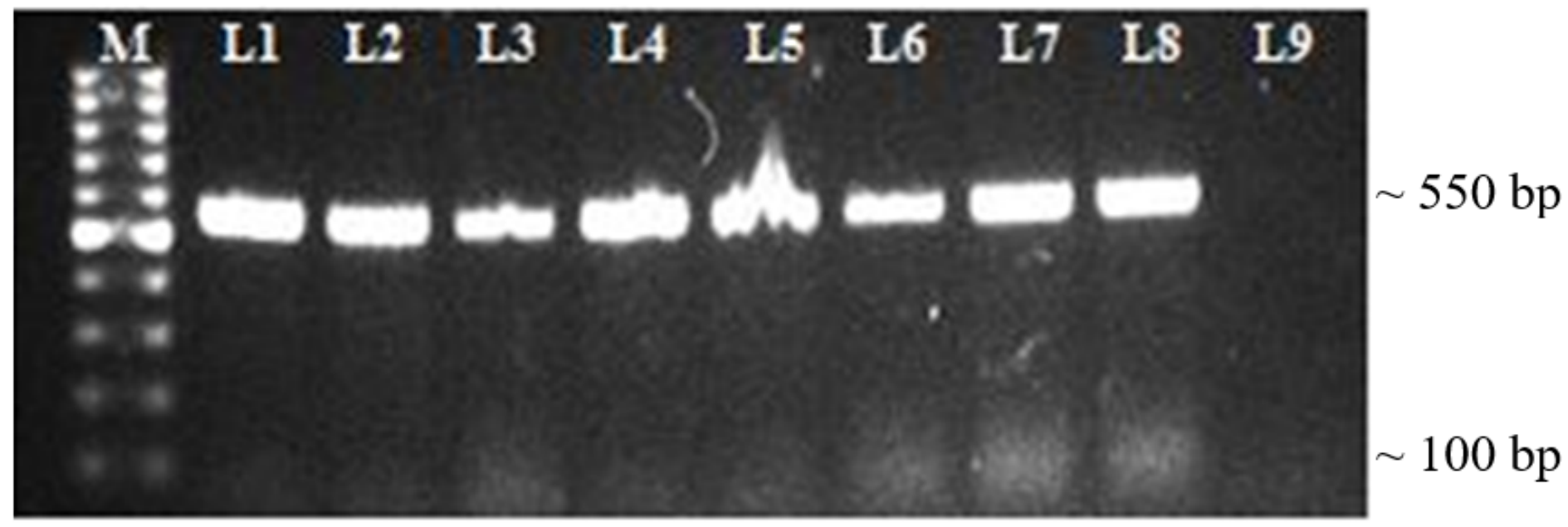

\section{Figure 3}

\section{PCR amplification of ITS region of Magnaporthe oryzae.}

Legand - Agarose gel electrophoresis of PCR amplicons of ITS region of Magnaporthe oryzae isolates infecting rice. Total DNA isolated from fungal mycelium on PDA medium used as template. The DNA samples analysed are from mycelium of fungal isolates on PDA medium from Lane 1- CBE 1, Lane 2- CBE 2, Lane 3- CBE 3, Lane 4- CBE 4, Lane 5- BSR, Lane 6- SAT, Lane 7- GB, Lane 8- positive control (Magnaporthe oryzae), Lane 9- nuclease free water (negative control)

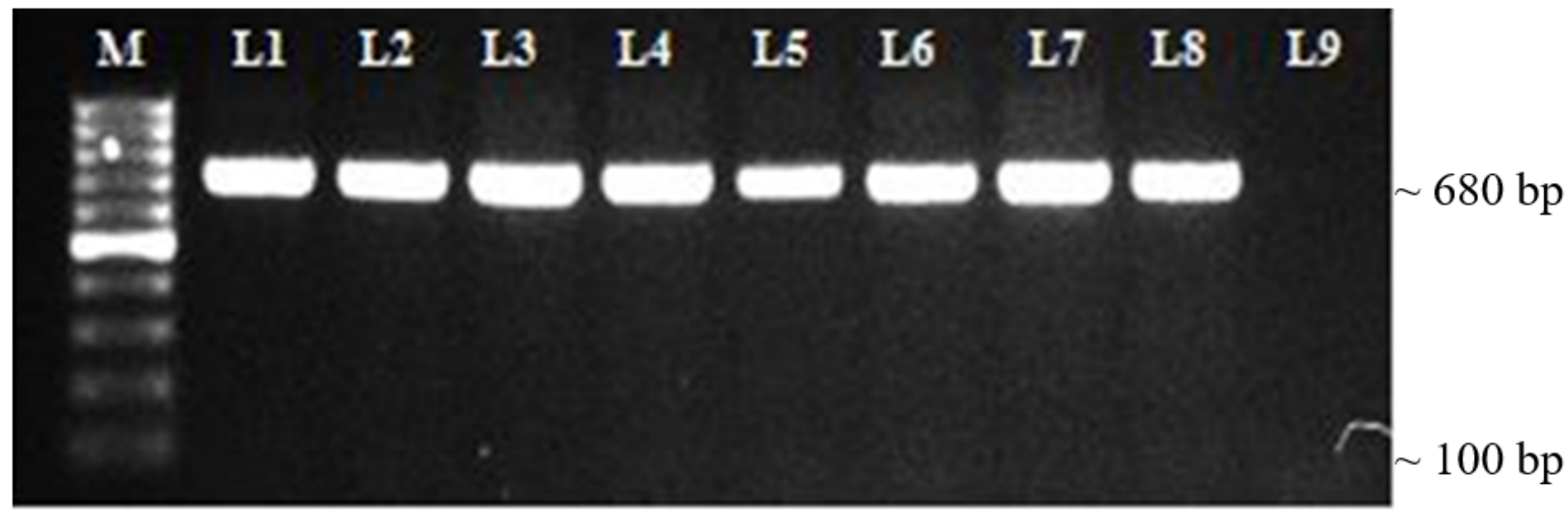

Figure 4

PCR amplification of Pot 2 transposon region of Magnaporthe oryzae.

Legand - Agarose gel electrophoresis of PCR amplicons of Pot 2 transposon region of Magnaporthe oryzae isolates infecting rice. Total DNA isolated from fungal mycelium on PDA medium used as template. The DNA samples analysed are from mycelium of fungal isolates on PDA medium from Lane 1- CBE 1, Lane 2- CBE 2, Lane 
3- CBE 3, Lane 4- CBE 4, Lane 5- BSR, Lane 6- SAT, Lane 7- GB, Lane 8- positive control (Magnaporthe oryzae), Lane 9- nuclease free water (negative control)
1
2
3
4
5

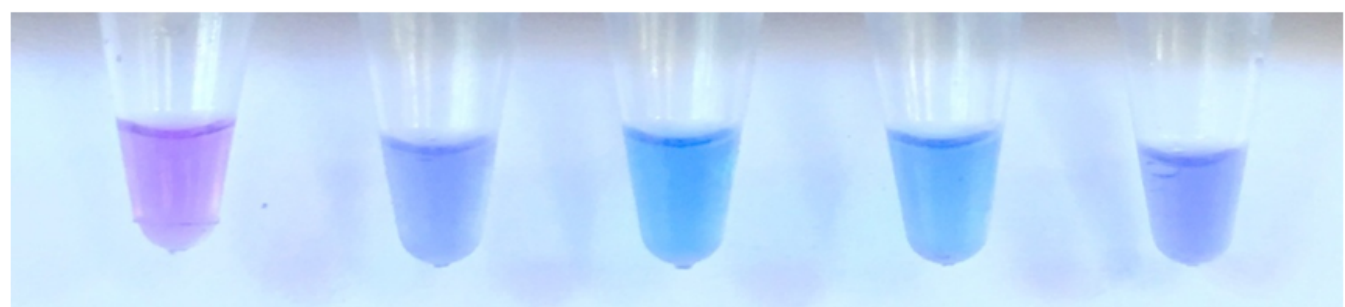

1

2

3

4

5

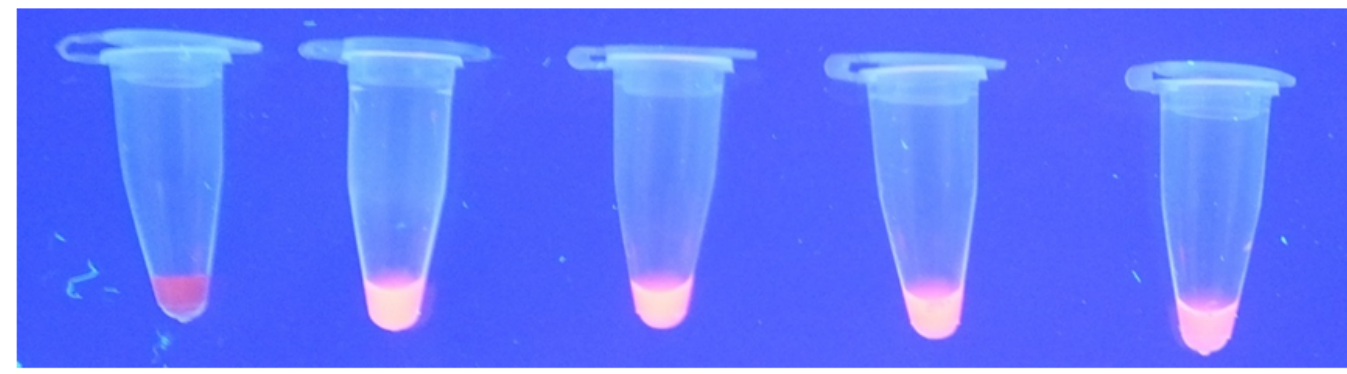
M
L1
L2
L3
L4
L5

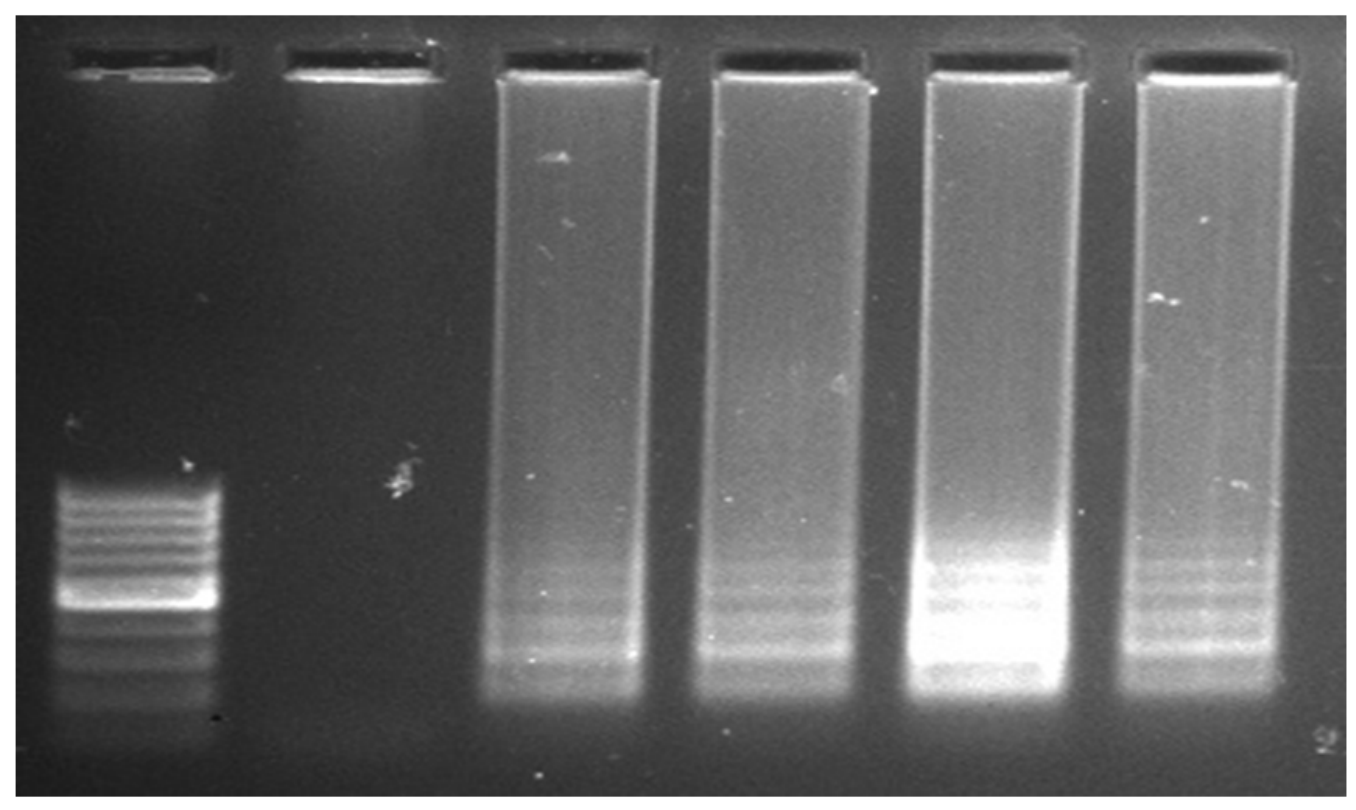

Figure 5

Optimization of incubation temperature in LAMP assay for the detection of Magnaporthe oryzae.

Legand - Optimization of incubation temperature for the detection of Pita 2 gene of Magnaporthe oryzae. Assessment was based on HNB visualization, EtBr fluorescence and agarose gel electrophoresis. Total DNA 
isolated from fungal conidia on PDA medium used as template. The DNA samples analysed are from Lane details: Lane $1-56{ }^{\circ} \mathrm{C}$, Lane $2-59{ }^{\circ} \mathrm{C}$, Lane $3-62{ }^{\circ} \mathrm{C}$, Lane $4-65^{\circ} \mathrm{C}$, Lane $5-68^{\circ} \mathrm{C}$.

$\begin{array}{llll}1 & 2 & 3 & 4\end{array}$

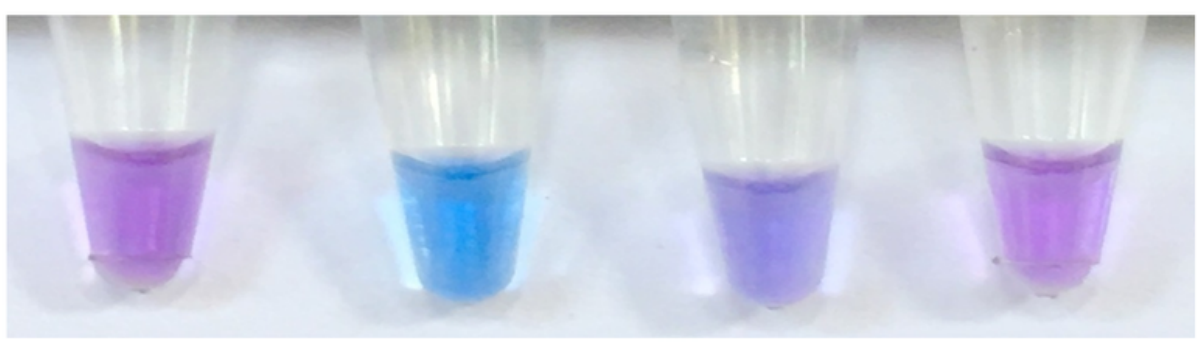
1
2
3
4

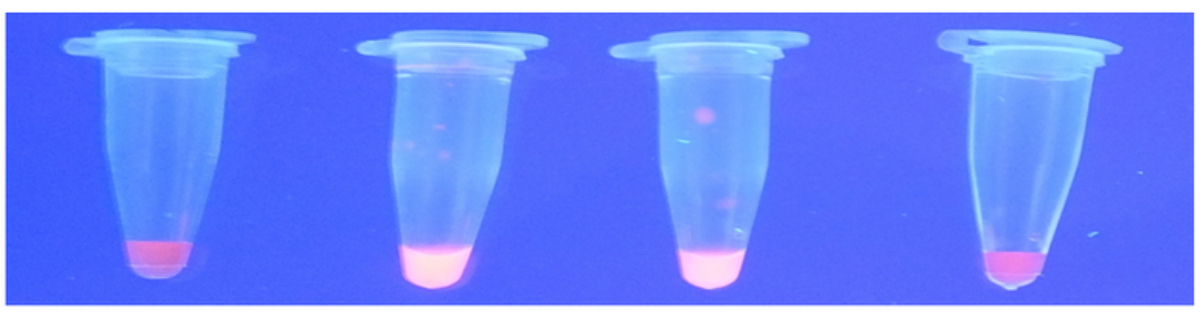

M

L1

L2

L3

L4

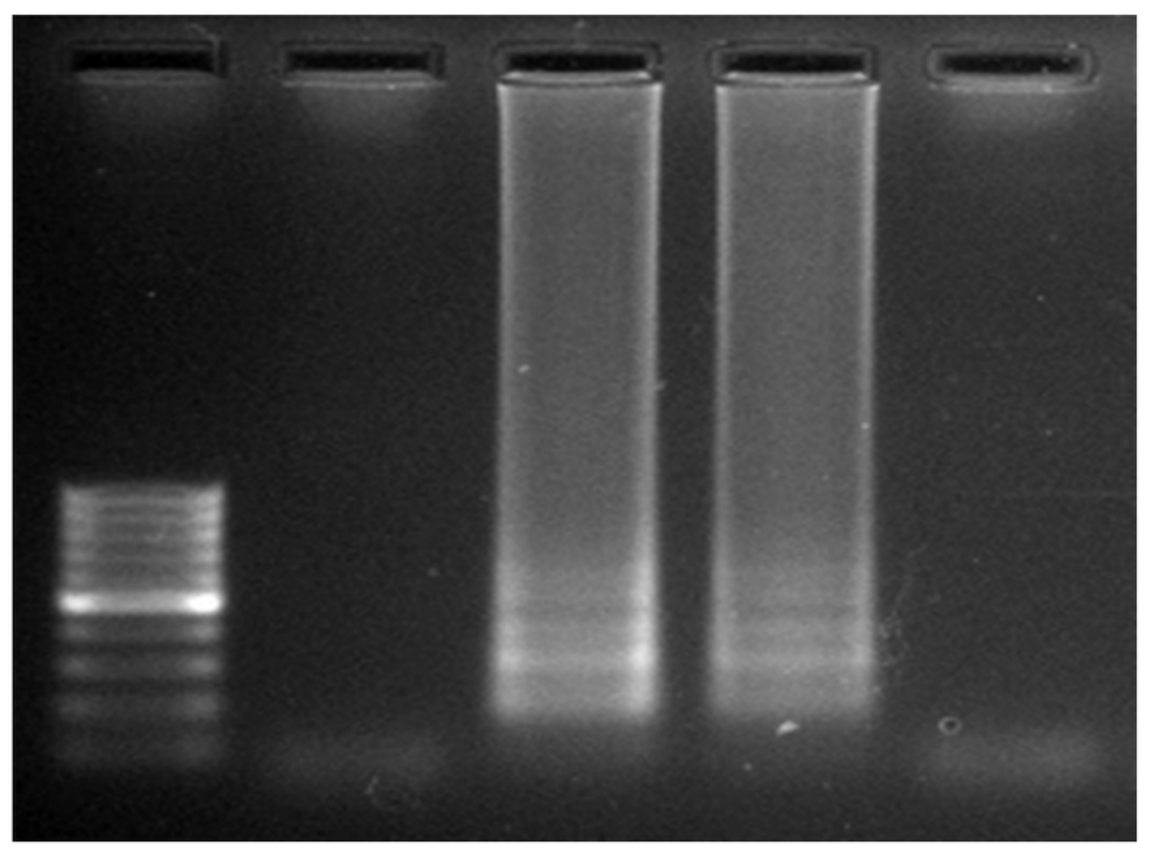

Figure 6

Optimization of incubation time in LAMP assay for the detection of Magnaporthe oryzae.

Legand -Optimization of incubation time for the detection of Pita 2 gene of Magnaporthe oryzae. Assessment was based on HNB visualization, EtBr fluorescence and agarose gel electrophoresis. Total DNA isolated from 
fungal conidia on PDA medium used as template. The DNA samples analysed are from Lane details: Lane 1-30 minutes, Lane 2 - 90 minutes, Lane 3- 60 minutes, Lane 4- 120 minutes.

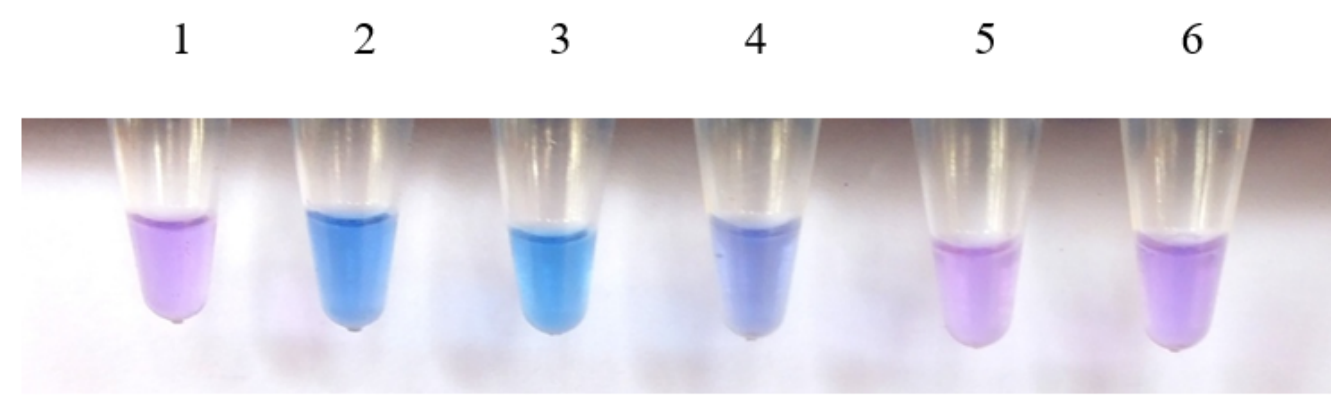
1
2
3
4
5
6
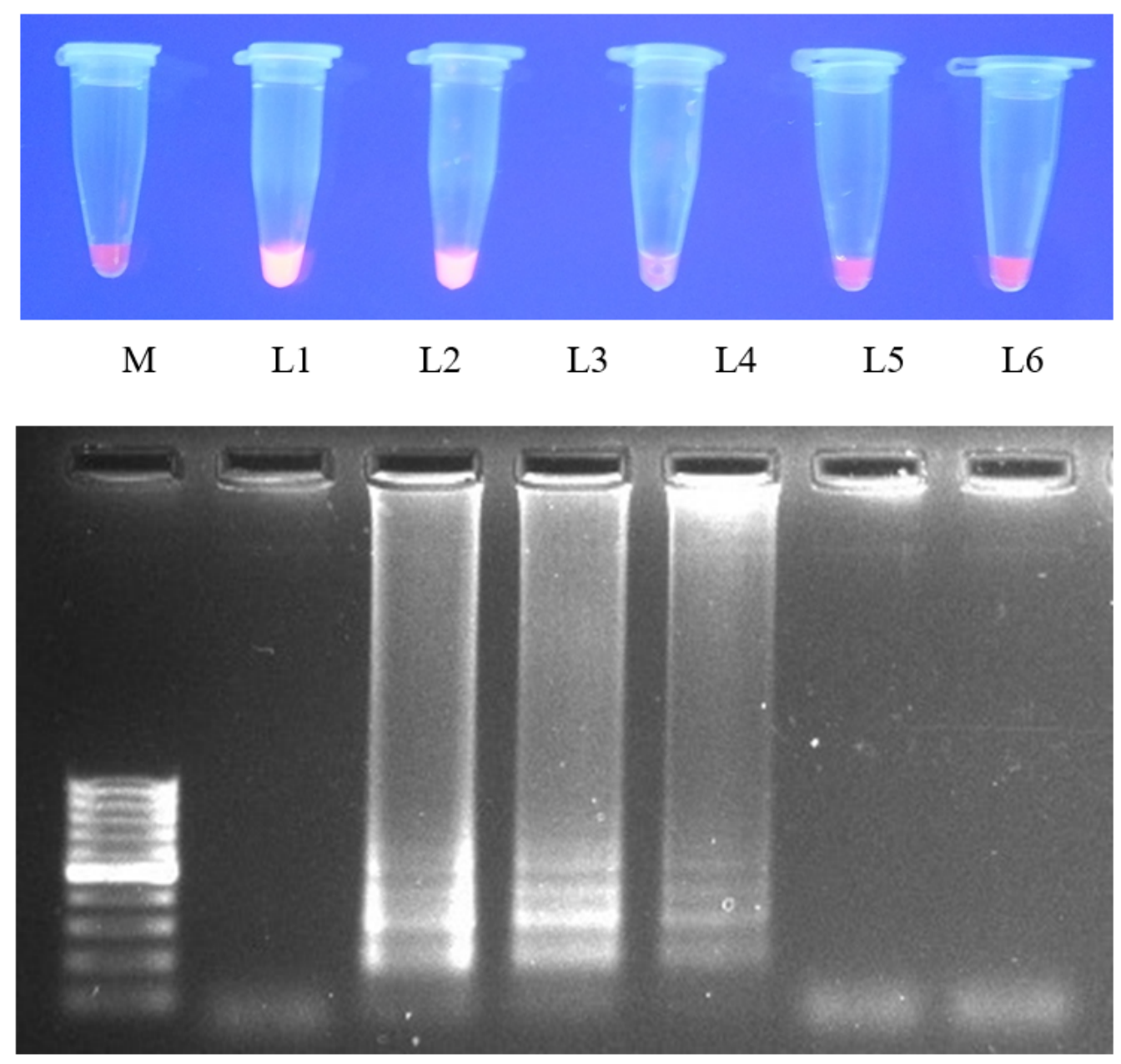

\section{Figure 7}

\section{Optimization of $\mathrm{MgSO}_{4}$ concentration in LAMP assay for the detection of Magnaporthe oryzae.}

Legand - Optimization of $\mathrm{MgSO}_{4}$ concentration for the detection of Pita 2 gene of Magnaporthe oryzae. Assessment was based on HNB visualization, EtBr fluorescence and agarose gel electrophoresis. Total DNA 
isolated from fungal conidia on PDA medium used as template. The DNA samples analysed are from Lane details: Lane 1- $2 \mathrm{mM} \mathrm{MgSO}_{4}$, Lane 2 - $4 \mathrm{mM} \mathrm{MgSO}_{4}$, Lane 3- $6 \mathrm{mM} \mathrm{MgSO}_{4}$, Lane 4- $8 \mathrm{mM} \mathrm{MgSO}_{4}$, Lane 5- 10 $\mathrm{mM} \mathrm{MgSO}_{4}$, Lane 6- nuclease free water (negative control)
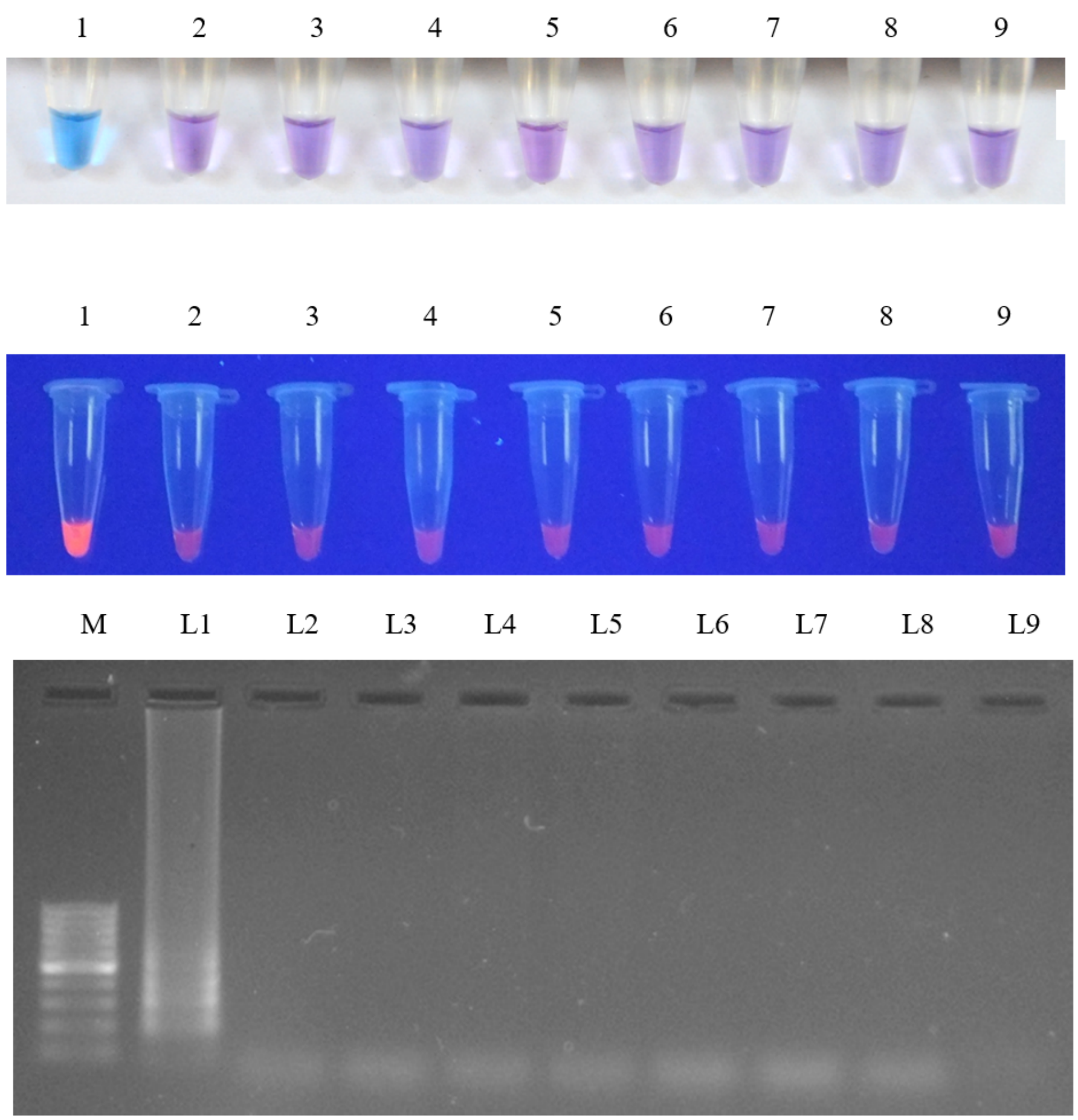

Figure 8

Specificity of the LAMP assay for the detection of Magnaporthe oryzae. 
Legand -Specificity of the LAMP assay targeting Pita 2 gene, colour visualization, EtBr visualization and agarose gel electrophoresis. Total DNA isolated from fungal conidia on PDA medium used as template. The DNA samples analysed are from Lane details: Lane 1- Magnaporthe oryzae, Lane 2- Helminthosporium oryzae, Lane 3Plasmopara viticola, Lane 4- Erysiphe necator, Lane 5- Fusarium oxysporum f.sp. cubense, Lane 6- Colletotrichum capsici, Lane 7- Pernoscleropsora sorghi, Lane 8- Sclerospora graminicola, Lane 9- nuclease free water (negative control)

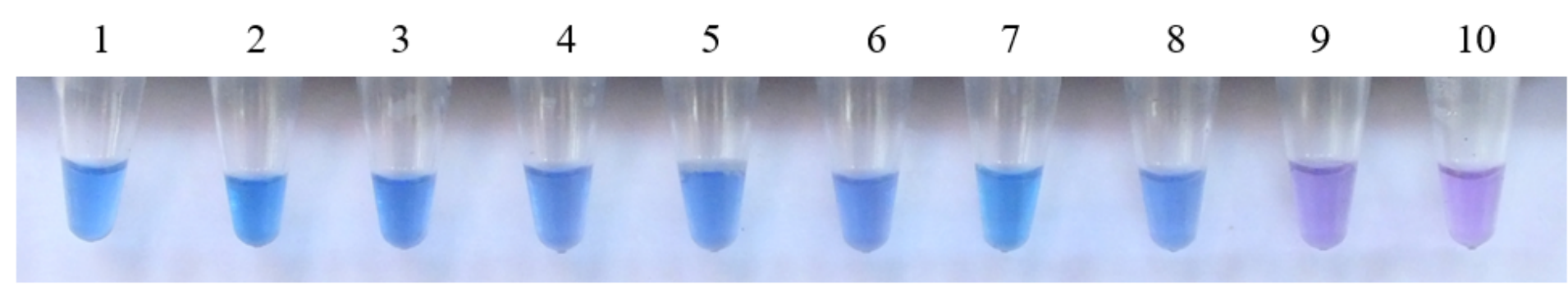
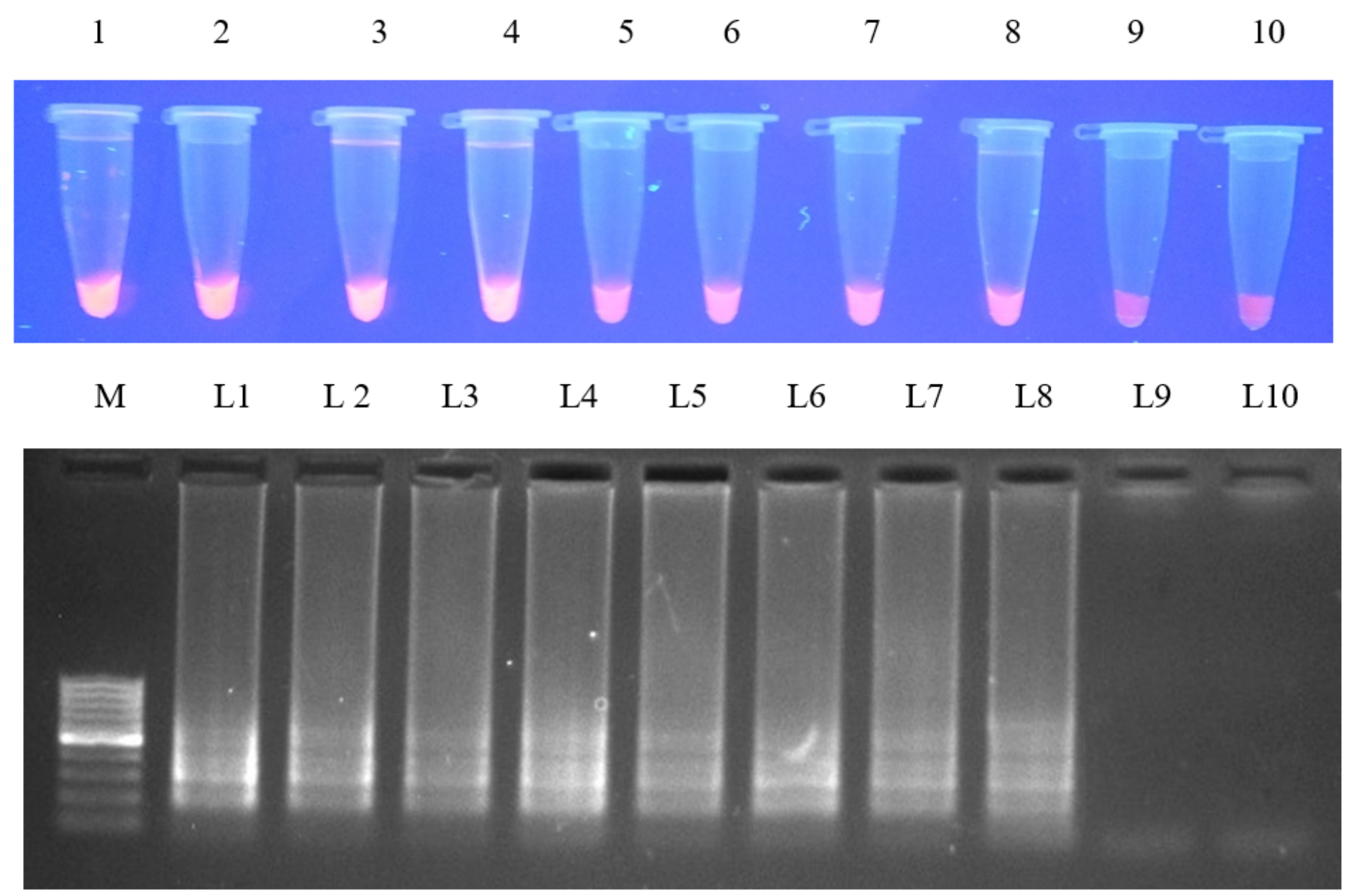

Figure 9

Sensitivity of the LAMP assay for the detection of Magnaporthe oryzae. 
Legand - Sensitivity of the LAMP assay targeting Pita 2 gene in serially diluted genomic DNA of Magnaporthe oryzae, colour visualization, EtBr visualization and agarose gel electrophoresis. Total DNA isolated from fungal conidia on PDA medium used as template. The DNA samples analysed are from Lane 1- $100 \mathrm{ng}$, Lane 2- $10 \mathrm{ng}$, Lane 3- 1 ng, Lane 4- 100 pg, Lane 5- 10 pg, Lane 6- 1 pg, Lane 7- 100 fg, Lane 8- 10 fg, Lane 9- 1 fg, Lane 10nuclease free water (negative control)

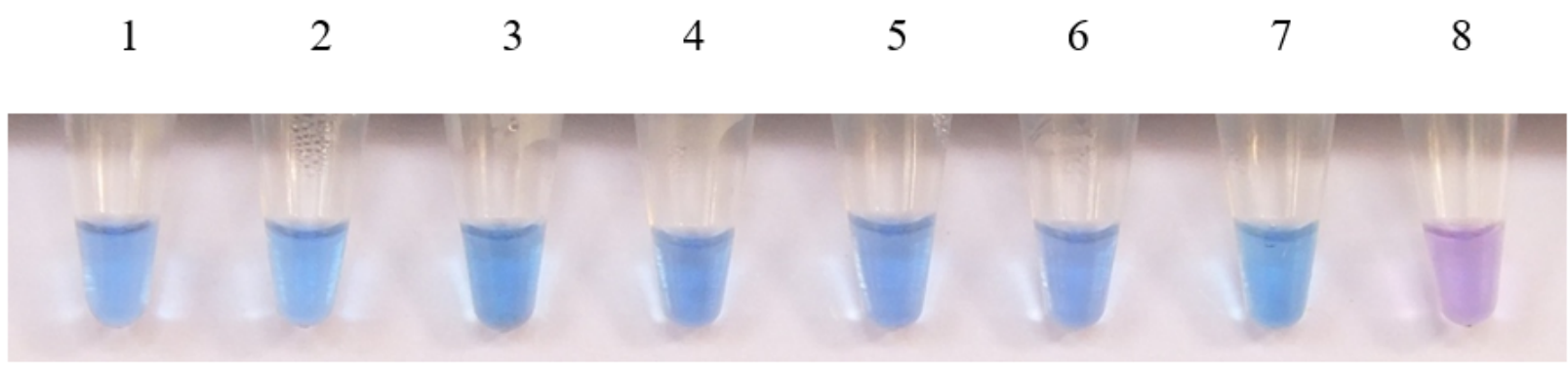

1

2

34

5

6

7

8

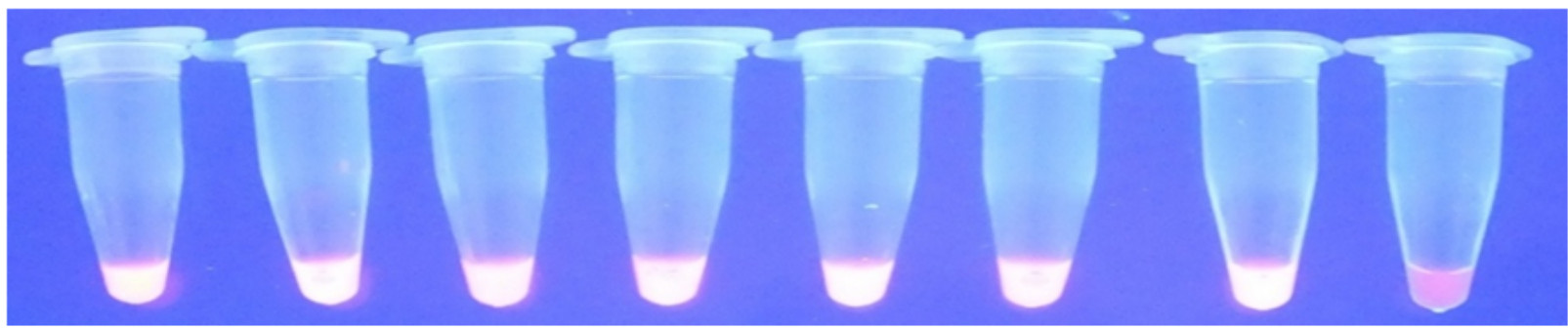
M
L1
L2
L3
L4
L5
L6
L7
L8

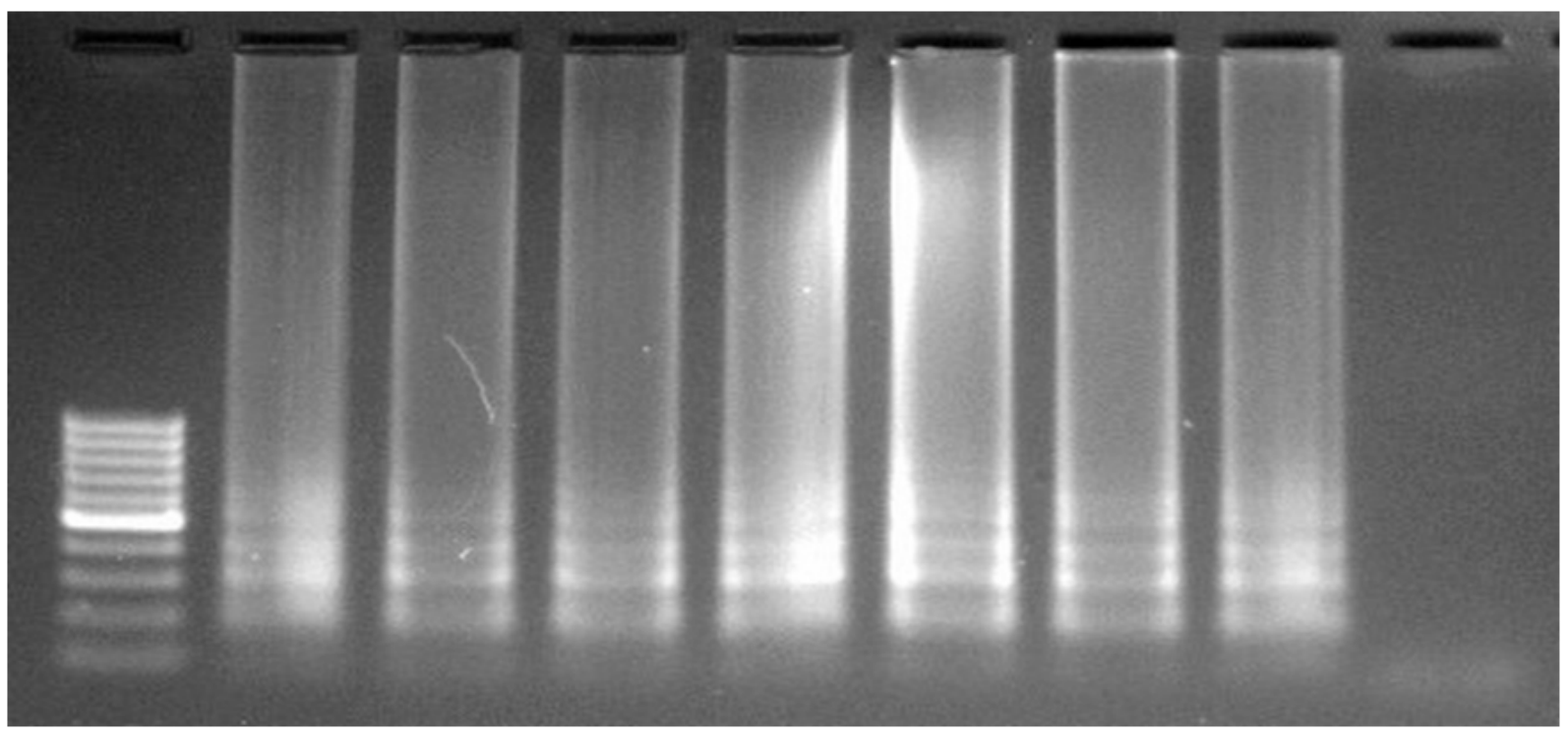

Figure 10 
Legand - Magnaporthe oryzae detection in LAMP, colour visualization, EtBr visualization and agarose gel electrophoresis. Total DNA isolated from fungal conidia on PDA medium used as template. The DNA samples analysed are from Lane 1- CBE 1, Lane 2- CBE 2, Lane 3- CBE 3, Lane 4- CBE 4, Lane 5- BSR, Lane 6- SAT, Lane 7GB, Lane 8- nuclease free water (negative control) 